\title{
Is aspartate aminotransferase to alanine aminotransferase ratio (De Ritis ratio) helpful in predicting breast cancer?
}

\section{Aspartat aminotransferaz/alanin aminotransferaz oranı (De Ritis oranı) meme kanserini tahmin etmede yardımcı olur mu?}

\author{
Abdullah Durhan ${ }^{1}$, Abdullah Şenlikci ${ }^{1}$, Ender Ergüder ${ }^{1}$, Marlen Süleyman ${ }^{1}$, Koray Koşmaz ${ }^{1}$, Ümit Mercan ${ }^{2}$, \\ Mevlüt Recep Pekcici ${ }^{1}$, Serap Erel $^{1}$
}

\begin{abstract}
Aim: De Ritis ratio (aspartate transaminase/alanine transaminase) may be a useful prognostic biomarker for certain malignant tumors. However, the predictive value of the De Ritis ratio before treatment in preoperative staging in patients with breast cancer is unknown. This study aimed to evaluate the De Ritis ratio in benign and malignant breast diseases and investigate the predictive value of it for breast cancer.

Methods: Retrospective analysis was made of the clinicopathological data of 301 patients with benign breas disease and breast cancer treated between April 2017 and April 2020 in a single center. 64 Patients were excluded from the study due to chronic illness or incomplete data. The relationship between the De Ritis ratio and clinicopathological findings before treatment was evaluated in patients. The Mann Whitney $U$ test and Kruskal Wallis test were used in the comparisons between groups.

Results: Of the total 237 patients, the number of patients with benign breast disease was 96 and the number of the patients with breast cancer was 141 . No statistically significant results were determined between the benign breast disease and breast cancer groups, in respect of pre-treatment evaluation of the De Ritis ratio and as a predictive factor for preoperative staging in molecular subtyping, tumor diameter, lymph node metastasis, and Ki 67 index.

Conclusion: It was concluded that the De Ritis ratio examined before treatment was not an independen predictive factor in breast cancer diagnosis and staging.
\end{abstract}

Keywords: De ritis ratio, aspartate transaminase, alanine transaminase, breast cancer, predictive factor

Öz

Amaç: De Ritis oranı (aspartat transaminaz/alanin transaminaz) belirli malign tümörler için yararlı bi prognostik biyobelirteç olabilir. Bununla birlikte, meme kanseri olan hastalarda tedavi öncesi incelenen De Ritis oranının preop evrelemede prediktif değeri büyük ölçüde bilinmemektedir. Bu çalışmanın amacı, benign ve malign meme hastalıklarında De Ritis oranını değerlendirmek ve bunun meme kanseri için prediktif değerini araştırmaktır.

Yöntemler: Nisan 2017- Nisan 2020 yılları arasında benign meme hastalığı ve meme kanserli 301 hastanın klinikopatolojik verileri tek bir merkezde retrospektif olarak analiz edildi. Kronik hastalığı olan veya veri eksiği olan 64 hasta çalışmadan çıkarıldı. De Ritis oranının tedavi öncesi değeri ile, hastaların klinikopatolojik bulguları arasındaki ilişki değerlendirildi. Gruplar arası karşılaştırmalarda Mann Whitney U testi ve Kruskal Wallis testi kullanıldı.

Bulgular: 237 hastada, benign meme hastalığı olan 96, meme kanseri olan hasta sayısı ise 141 idi. De ritis oranın tedavi öncesi değeri ile, benign meme hastalığı ve meme kanseri arasında, ayrıca meme kanserinde prognostik faktör olan moleküler subtiplendirme, tümör çapı, lenf nodu metastazı ve Ki 67 indeksinde preoperatif evrelemede prediktif faktör olarak istatisksel anlamlı sonuçlara ulaşılamadı.

Sonuç: Tedavi öncesi incelenen De ritis oranın meme kanseri evrelemesinde bağımsız prediktif faktör olmadığı sonucuna ulaşıldı.

Anahtar kelimeler: De ritis oranı, aspartat transaminaz, alanin transaminaz, meme kanseri, prediktif faktör
${ }^{1}$ University of Health Sciences, Ankara Training and Research Hospital, Department of General Surgery, Ankara, Turkey.

2 University of Health Sciences, Şanlıurfa Mehmet Akif İnan Training and Research Hospital, Department of General Surgery, Şanlıurfa, Turkey.

iD

AD: 0000-0002-5622-9678

AȘ: 0000-0002-4321-4004

EE: 0000-0001-5289-3718

MS: 0000-0001-6979-4150

KK: 0000-0003-2111-3162

ÜM: 0000-0001-5060-6789

MRP:0000-0002-5566-8134

SE: $0000-0001-7365-883 \mathrm{X}$

Ethics Committee Approval: Ethics committee approval was received from Ankara Training and Research Hospital, Clinical Research Ethic Committee (27.08.2020, 2020/20:360).

Etik Kurul Onayı: Ankara eğitim ve Araştırma Hastanesi etik kurulundan onay alınmıștır (27.08.2020, 2020/20:360).

Conflict of Interest: No conflict of interest was declared by the authors.

Çıkar Çatışması: Yazarlar çıkar çatışması bildirmemistir.

Financial Disclosure: The authors declared that thi study has received no financial support.

Finansal Destek: Yazarlar bu çalışma için finansal destek almadıklarını beyan etmișlerdir.

Gelis Tarihi / Received: 05.01.2021

Kabul Tarihi / Accepted: 08.03.2021

Yayın Tarihi / Published: 01.04.2021

Sorumlu yazar / Corresponding author Abdullah Durhan

Adres/Address: University of Health Sciences, Ankara Training and Research Hospital, Department of General Surgery, Altındağ, Ankara, Turkey.

e-posta: durhanabdullah@gmail.com Tel/Phone: +90 5556984527

Copyright $(\subset$ ACEM 


\section{Introduction}

Breast cancer is the most common malignancy in women and the second most frequent cause of cancer-related death [1]. Since most of the patients are diagnosed at an advanced stage, the response and prognosis of the disease are negatively affected. The effective treatment of breast cancer is mostly based on early diagnosis and a definitive treatment plan. Mammography is the most effective screening method for breast cancer diagnosis, but there are some limitations to this method, such as the high cost, radiation exposure, and the low number of experienced breast radiologists. Alternatively, many tumor markers have been developed, such as serum carcinoembryonic antigen (CEA) and carbohydrate antigen (CA15-3). Unfortunately, the use of these markers in the diagnosis of breast cancer is limited due to inadequate sensitivity and specificity [2, 3]. The development of cancer screening tests and cancer biomarkers with clinical utility would overcome these problems.

Aspartate aminotransaminase (AST) and alanine aminotransaminase (ALT) are liver enzymes commonly used in clinical laboratory tests. These enzymes released from liver cells into the blood are produced by both malignant and nonmalignant cells. AST also acts in the brain, liver, gastric mucosa, adipose tissue, skeletal muscle, and kidneys, especially the liver and heart muscle. ALT is predominantly found in the liver, whereas in other tissues, a small amount can be detected [4, 5]. AST and ALT values are stable in normal healthy individuals but may be affected by many other non-tumor-related factors, including chronic hepatitis, coronary heart disease, impaired kidney function, and medications. As the numerical values are unstable when they act as single predictors, the combination of AST and ALT is more suitable as a composite parameter. The AST-ALT ratio, also called the De Ritis ratio, was originally defined by De Ritis in 1957 [6]. Although the De Ritis ratio was first used to identify viral hepatitis and some chronic liver diseases, it has been identified in recent studies as an independent prognostic factor for the prediction of disease stage and patient survival in some malignancies [7-9].

In the preoperative period, many laboratories and radiological tests are performed to determine the stage of cancer. Therefore, surgical planning and the neoadjuvant or adjuvant systemic treatment plan is decided with a multidisciplinary approach before the operation according to these test results. The De Ritis ratio is an inexpensive, simple and non-invasive test, which can be useful as a predictive factor in preoperative staging.

This study aimed to evaluate the De Ritis ratio in benign and malignant breast diseases and investigate the predictive value of it for breast cancer.

\section{Material and methods}

Clinical Research Ethics Committee approved the study. Approval date and number: 27.08.2020, 2020/20:360. Informed consent was not taken due to the retrospective nature of the study.

301 women who underwent surgery with a diagnosis of benign breast disease or breast cancer in the General Surgery Department between April 2017 and April 2020 were retrospectively evaluated. A total of 64 patients were excluded from the study for various reasons; 1) known chronic liver disease (eg, chronic viral hepatitis, non-alcoholic fatty liver disease, cirrhosis), 2) receiving neoadjuvant chemotherapy or stage 4 breast cancer 3), recurrent tumor, 4) other known malignancy, 5) incomplete or unavailable data (Figure 1). The remaining 237 women were divided into two groups as benign breast disease (Group 1) and breast cancer (Group 2) according to the histopathological results.

Figure 1: Patient selection.

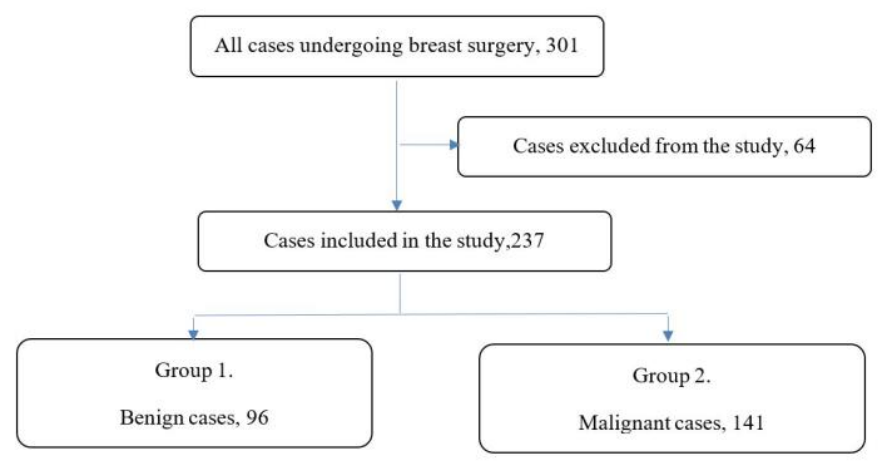

Data related to age, liver function tests (AST, ALT) before surgery, and in Group 2 molecular subtypes (luminal A, luminal B, triple-negative, and HER2 +), diameter of the tumor, lymph node involvement, and $\mathrm{Ki} 67$ index were retrieved from the hospital database. The De Ritis ratio was calculated by the simple proportioning method in the electronic system. Tumor staging was applied according to the American Joint Committee on Cancer (AJCC) 8th edition tumor, lymph grade metastasis, distant metastasis (TNM) staging system.

\section{Statistical Analysis}

Data obtained in the study were analyzed statistically using SPSS vn 21 software. The conformity of the data to normal distribution was assessed using the Kolmogorov-Smirnov and Shapiro-Wilk tests. Normally distributed parametric data were presented as mean \pm standard deviation (SD) values and the significance of intergroup variance was analyzed using the Student's t-test. The Mann Whitney U and Kruskal Wallis tests were used in the analysis between the groups. A value of $\mathrm{p}<0.05$ was considered statistically significant.

\section{Results}

Of the total 237 patients, Group 1 included 96 (40.50\%) patients with a mean age of $52.07 \pm 10.83$ years, and Group 2 included 141 (59.49\%) patients with a mean age of $54.50 \pm 12.15$ years. There was no statistical significance between groups according to the ages $(\mathrm{p}=0.095)$. The AST, ALT values and De Ritis ratio were not statistically significant in Group 1 and Group $2(\mathrm{p}=0.058, \mathrm{p}=0.148, \mathrm{p}=0.908$, respectively) (Table 1$)$.

Table 1. Comparison of the Impact of the De Ritis ratio in Benign Breast Disease and Breast Cancer.

\begin{tabular}{lccc} 
& $\begin{array}{c}\text { Group 1 } \\
\text { (benign) }\end{array}$ & $\begin{array}{c}\text { Group 2 } \\
\text { (malignant) }\end{array}$ & \\
\cline { 2 - 3 } & Mean \pm sd & Mean \pm sd & p value \\
\hline Age & $52.07 \pm 10.83$ & $54.50 \pm 12.15$ & 0.095 \\
AST (U/L) & $18.17 \pm 5.32$ & $20.13 \pm 10.44$ & 0.058 \\
ALT (U/L) & $17.42 \pm 8.49$ & $19.85 \pm 14.84$ & 0.148 \\
AST/ALT ratio & $1.19 \pm 0.49$ & $1.17 \pm 0.41$ & 0.908 \\
\hline
\end{tabular}

In the molecular subtype staging of the Group 2 patients, $72(51.06 \%)$ were luminal A, $54(38.29 \%)$ were luminal $\mathrm{B}, 4(2.83 \%)$ were triple-negative and $11(7.80 \%)$ were HER2 +. No statistically significant difference was determined between 
the molecular subtypes in respect of the De Ritis ratio $(\mathrm{p}=$ 0.850) (Table 2).

Table 2. Comparison of the Impact of the De Ritis Ratio on Prognosis in Breast Cancer Subgroups

\begin{tabular}{|c|c|c|c|c|}
\hline $\begin{array}{l}\text { Group } 2 \\
\text { (malignant) }\end{array}$ & $\begin{array}{c}\text { Number of } \\
\text { Cases } \\
(n=141)\end{array}$ & $\begin{array}{c}\text { Percentage } \\
(\%)\end{array}$ & $\begin{array}{c}\mathrm{AST} / \mathrm{ALT} \\
\text { mean } \pm \mathrm{SD}\end{array}$ & $\mathrm{p}$ value \\
\hline Molecular subtype & & & & 0.850 \\
\hline Luminal A & 72 & 51.06 & $1.15 \pm 0.35$ & \\
\hline Luminal B & 54 & 38.29 & $1.18 \pm 0.46$ & \\
\hline Triple negative & 4 & 2.83 & $1.07 \pm 0.39$ & \\
\hline HER 2+ & 11 & 7.80 & $1.24 \pm 0.51$ & \\
\hline Tumor size & & & & 0.722 \\
\hline $\mathrm{T} 1(\leq 2 \mathrm{~cm})$ & 70 & 49.64 & $1.17 \pm 0.37$ & \\
\hline $\mathrm{T} 2(<2 \mathrm{~cm}, \leq 5 \mathrm{~cm})$ & 57 & 40.42 & $1.19 \pm 0.49$ & \\
\hline $\mathrm{T} 3(>5 \mathrm{~cm})$ & 14 & 9.92 & $1.09 \pm 0.28$ & \\
\hline $\begin{array}{l}\text { Lymph node } \\
\text { involvement }\end{array}$ & & & & 0.154 \\
\hline NO & 93 & 65.95 & $1.21 \pm 0.42$ & \\
\hline $\mathrm{N} 1, \mathrm{~N} 2$ & 48 & 34.04 & $1.10 \pm 0.37$ & \\
\hline Ki 67 & & & & 0.198 \\
\hline$<20$ & 92 & 65.24 & $1.20 \pm 0.43$ & \\
\hline$\geq 20$ & 49 & 34.75 & $1.10 \pm 0.37$ & \\
\hline
\end{tabular}

AST: Aspartate transaminase, ALT: Alanine transaminase, SD: Standard deviation, HER2: Human epidermal growth factor receptor 2

According to tumor size, $70(49.64 \%)$ patients were T1, $57(40.42 \%)$ were T2 and $14(9.92 \%)$ were T3. There was no statistically significant difference in the De Ritis ratio between tumor sizes $(\mathrm{p}=0.722)$ (Table 2).

There was no lymph node metastasis in $93(65.95 \%)$ of the patients, and $48(34.04 \%)$ had lymph node metastasis. No statistically significant difference was found in the De Ritis ratio according to the presence of lymph node metastasis $(\mathrm{p}=0.154)$ (Table 2).

In $92(65.24 \%)$ patients, the Ki-67 index was <20, and in $49(34.75 \%)$ it was $>20$. There was no statistically significant difference in the De Ritis ratio according to the Ki 67 index ( $\mathrm{p}=$ 0.154) (Table 2).

\section{Discussion}

The De Ritis ratio is frequently used as a predictive index in various diseases including acute stroke, arteriosclerosis, kidney, and respiratory dysfunction, and critical limb ischemia [10-13]. The effect of the De Ritis ratio on cancer prognosis has also been reported in various studies [14-16]. Wu et al. found in a meta-analysis involving 9400 patients that high De Ritis ratio before treatment was a prognostic factor for overall survival, cancer-specific survival, and disease-free survival in solid tumors (renal cell cancer, urinary tract urethral carcinoma, bladder cancer, and liver cancer) [17]. In a retrospective study of 109 patients by Nishikawa et al, it was found that the De Ritis ratio in urinary tract urothelial carcinoma was an independent predictive factor in TNM staging [18]. Katzke et al. conducted a prospective randomized cohort study and demonstrated that a high ratio of De Ritis before treatment in all four cancers (lung, prostate, breast, and colorectum) increased mortality but it was seen to only increase the risk of prostate cancer and not the risk of breast cancer [19]. In contrast, Thriveni et al. reported that the De Ritis ratio before treatment statistically significantly increased TNM staging according to stages in breast cancer and could be an independent predictive factor [4]. However, among these studies, there are very few studies on breast cancer, and very different results have been found in terms of the De Ritis ratio being a predictive and prognostic factor in breast cancer. Therefore, the value of the De Ritis ratio on breast cancer prognosis remains uncertain. The current study was conducted to investigate the predictive factor effect of the De Ritis ratio in breast cancer preoperative staging. The study results showed that the De Ritis ratio did not increase the risk of breast cancer, which was consistent with the findings of Katzke et al. [18]. Contrary to the study by Thriveni et al. [4], the results of the current study demonstrated that the De Ritis ratio does not increase statistically significantly according to stages and tumor diameter in the TNM staging system. In addition to these studies, among the molecular subtypes (luminal A, luminal B, triple-negative, and HER2 +), which are important prognostic indicators in breast cancer, the De Ritis ratio was not statistically significant in the Ki 67 index. It may be because of the smaller sample size of the T3 group and exclusion of the patients at stage 4 , as the De Ritis ratio has been found to be more significant in the advanced stage.

Hypotheses related to the high De Ritis ratio in cancer patients have stated that AST is predominantly found in the mitochondria of cells and ALT is found only in hepatocyte cytoplasm. Therefore, in cases involving tissue damage, mitochondrial DNA is damaged due to excessive release of reactive oxygen species, which can cause serious tissue damage and leads to the release of more mitochondrial enzymes [5]. Oxidative stress parameters and inflammatory markers increase cancer development and increase the De Ritis ratio. A second hypothesis states that cancer cells support more aerobic glycolysis than normal cells, and AST is known to play a vital role in aerobic glycolysis. This pathological condition leads to the activation of more AST than ALT in rapidly growing cancer tissues [20]. A third hypothesis is that oxidative stress and inflammation can cause liver damage. Therefore, the high De Ritis ratio may be a prognostic factor associated with the overall survival (OS) of patients with different types of cancer [21].

Limitations of this study can be said to be the retrospective design, the limited number of patients, the exclusion of stage 4 patients, and the unequal distribution of patients among the subgroups.

In conclusion, the results of this study showed that the pre-treatment De Ritis ratio was not an independent predictive factor differentiating between benign breast disease and breast cancer, in addition to molecular subtyping, tumor diameter, lymph node metastasis, and $\mathrm{Ki} 67$ index preoperative staging in breast cancer. There are few studies in the literature on the fact that the De Ritis ratio is an independent predictive factor in breast cancer staging and different results have been obtained in those studies. Therefore, to overcome the above-mentioned limitations, there is a need for more comprehensive clinical trials to be conducted to confirm the prognostic role of the De Ritis ratio before treatment in preoperative staging in patients with malignancies.

\section{References}

1. Sharma R. Breast cancer incidence, mortality and mortalityto-incidence ratio (MIR) are associated with human development, 1990-2016: evidence from Global Burden of Disease Study 2016. Breast Cancer (Tokyo, Japan). 2019;26:428-45.

2. Cardoso F, Saghatchian M, Thompson A, Rutgers E, Committee TCS. Inconsistent criteria used in American Society of Clinical Oncology 2007 update of recommendations for the use of tumor markers in breast cancer. J Clin Oncol. 2008;26:2058-9.

3. Harris L, Fritsche H, Mennel R, Norton L, Ravdin P, Taube S, et al. American Society of Clinical Oncology 2007 update of recommendations for the use of tumor markers in breast cancer. J Clin Oncol. 2007;25:5287-312. 
4. Thriveni K, James R, Krisnamoorthy L, Deshmane V, Bapsy PP, Ramaswamy G. Serum Transaminases Ratio in Breast Cancer Patients. Austral-Asian J Cancer. 2009;8:207-9.

5. Moss and Henderson, A.R. Clinical Enzymology. In: Burtis, C.A. and Ashwood, E.R., editors. Tietz Textbook of Clinical Chemistry. 3rd ed. Saunders: Philadephia;1999.p.617-77.

6. De Ritis F, Coltorti M, Giusti G. An enzymic test for the diagnosis of viral hepatitis; the transaminase serum activities. Clin Chim Acta. 1957;2:70-4.

7. Bezan A, Mrsic E, Krieger D, Stojakovic T, Pummer K, Zigeuner R, et al. The Preoperative AST/ALT (De Ritis) Ratio Represents a Poor Prognostic Factor in a Cohort of Patients with Nonmetastatic Renal Cell Carcinoma. J Urol. 2015;194:30-5.

8. Thornburg JM, Nelson KK, Clem BF, Lane AN, Arumugam S, Simmons A, et al. Targeting aspartate aminotransferase in breast cancer. Breast Cancer Res. 2008;10:R84.

9. Lee H, Lee SE, Byun SS, Kim HH, Kwak C, Hong SK. De Ritis ratio (aspartate transaminase/alanine transaminase ratio) as a significant prognostic factor after surgical treatment in patients with clear-cell localized renal cell carcinoma: a propensity scorematched study. BJU Int. 2017;119:261-7.

10. Gao F, Chen C, Lu J, Zheng J, Ma XC, Yuan XY, et al. De Ritis ratio (AST/ALT) as an independent predictor of poor outcome in patients with acute ischemic stroke. Neuropsychiatr Dis Treat. 2017;13:1551-7.

11. Liu Y, Zhao P, Cheng M, Yu L, Cheng Z, Fan L, et al. AST to ALT ratio and arterial stiffness in non-fatty liver Japanese population:a secondary analysis based on a cross-sectional study. Lipids Health Dis. 2018;17:275.

12. Pilarczyk K, Carstens H, Heckmann J, Canbay A, Koch A, Pizanis N, et al. The aspartate transaminase/alanine transaminase (DeRitis) ratio predicts mid-term mortality and renal and respiratory dysfunction after left ventricular assist device implantation. Eur J Cardiothorac Surg. 2017;52:781-8.

13. Rief P, Pichler M, Raggam R, Hafner F, Gerger A, Eller P, et al. The AST/ALT (De-Ritis) ratio: A novel marker for critical limb ischemia in peripheral arterial occlusive disease patients. Medicine (Baltimore). 2016;95:e3843.

14. Liu L, Wang W, Zhang Y, Long J, Zhang Z, Li Q, et al. Declined Preoperative Aspartate Aminotransferase to Neutrophil Ratio Index Predicts Poor Prognosis in Patients with Intrahepatic Cholangiocarcinoma after Hepatectomy. Cancer Res Treat. 2018;50:538-50.

15. Mori K, Janisch F, Mostafaei H, Kimura S, Lysenko I, Karakiewicz PI, et al. Prognostic role of preoperative De Ritis ratio in upper tract urothelial carcinoma treated with nephroureterectomy. Urol Oncol. 2020;38:601.e17-601.e24.

16. Ha YS, Kim SW, Chun SY, Chung JW, Choi SH, Lee JN, et al. Association between De Ritis ratio (aspartate aminotransferase/alanine aminotransferase) and oncological outcomes in bladder cancer patients after radical cystectomy. BMC Urol. 2019;19:10.

17. Wu J, Chen L, Wang Y, Tan W, Huang Z. Prognostic value of aspartate transaminase to alanine transaminase (De Ritis) ratio in solid tumors: a pooled analysis of 9,400 patients. Onco Targets Ther. 2019;12:5201-13.

18. Nishikawa M, Miyake H, Fujisawa M. De Ritis (aspartate transaminase/alanine transaminase) ratio as a significant predictor of recurrence-free survival in patients with upper urinary tract urothelial carcinoma following nephroureterectomy. Urol Oncol. 2016;34:417.e9-417.e15.

19. Katzke V, Johnson T, Sookthai D, Husing A, Kuhn T, Kaaks R. Circulating liver enzymes and risks of chronic diseases and mortality in the prospective EPIC-Heidelberg case-cohort study. BMJ Open. 2020;10.

20. Dang CV. Links between metabolism and cancer. Genes Dev. 2012;26:877-90.

21. Zheng J, Seier K, Gonen M, Balachandran VP, Kingham TP, D'Angelica MI, et al. Utility of Serum Inflammatory Markers for Predicting Microvascular Invasion and Survival for Patients with Hepatocellular Carcinoma. Ann Surg Oncol. 2017;24:3706-14. 